\title{
Tenure, Management, Degradation of Farmlands, Pasturelands and Household /Livestock Water Resources in the Vina-Division Adamawa-Cameroon
}

\author{
Ahmadou Bouba (Corresponding author) \\ Institute of Research for Agriculture and for Development of Wakwa, Adamawa-Region \\ Cameroon, P. O. Box 65, Ngaoundere, Cameroon \\ Tel: 237-9627-9581Ｅ-mail: boubabello28@yahoo.com
}

\begin{abstract}
Amougou Amougou Francois
Institute of Research for Agriculture and for Development of Wakwa Adamawa-Region Cameroon, P. O. Box 65, Ngaoundere, Cameroon

Tel: 237-9984-1096_E-mail: jra_fr@yahoo.fr
\end{abstract}

\section{Henrietta Ngangyung}

Institute of Research for Agriculture and for Development of Wakwa Adamawa-Region Cameroon, P. O. Box 65, Ngaoundere, Cameroon

Tel: 237-7797-0113_E-mail:ng_henrietta@yahoo.com

\section{SALE Abou}

Institute of Research for Agriculture and for Development of Maroua, Fare North-Region Cameroon, P. O. Box 12 Maroua, Cameroon

Tel: 237-77577835Ｅ-mail: saleabou@yahoo.fr

Received: November 3, 2012 Accepted: November 8, 2012 Published: December 31, 2012 doi:10.5296/jee.v3i1.2912 URL: http://dx.doi.org/10.5296/jee.v3i1.2912 


\section{Abstract}

The essential natural resources such as arable soils, the household and pastoral water and the vegetation of the Vina Division are rapidly deteriorating these last recent years. The lowering fertility level of farm lands, the degradation of vegetation on pasture lands, and the insufiancy of household water and for animals are the observed indicators. Inded it was for this work to determine wether the actual ownership modalities or management practices are causes of the degradation or natural parameters could be associated to them?. Four localities included; Dibi, Mbang-Mboum, Mbe and Tourningal hav been choosen as study sites for investigation. From the study of the Adamawa Regional and Vina Divisional pedologic maps, from the observation and data collected from the field work, the soils of the four villages can be put into two major groups; ferruginous for Mbang-Mboum and Mbe, ferralitic for Dibi and Tourningal. Naturally these soils are poor in nutrient and were compacted by the permanent movements of animals. From the entertainment, observation and from land survey results, the access modalities or appropriation for resources are by donation, inheritage, man labour and rarely by renting. Sale of lands is strictly forbidden by local authorities particularly in Mbang-Mboum and in Mbé. Till to date, the working tools and management systems are at the traditional state. They do not know how to proceed for obtaining certificate of occupancy. Tey are not informed about the 1974 domanial laws. Any one can easily abandon either his or her farm or pasture land to another when the potential productivity of the land is decreasing. The access or appropriation modalities are based on social relationships then can be easily negociated. From exhaustive survey of all water resources ( such as local wells, bore holes, rivers, natural and artificial lakes) of the four localities, we found that in Mbé, the water resources dry rapidly as soon as the raining season is ending by November. In Mbang-Mboum, the three bore holes of the village can not more provide and satisfy the high demand of potable water for the increasing number of the population. The statistical analysis by chi-square $\left(\mathrm{X}^{2}\right)$ with 0.05 probability and the result from $\mathrm{HO}, \mathrm{H} 1$ test shows that the actual access modalities are the major causes of the rapidly degradation of the resources beside natural parameters such as the geographical location of the Vina Division, the chemical structure of soils, the irregular volume of raining water and climatic change effects. All this encourage poor and traditional management with no conscious on long term resource conservation. The agriculturer or pastoralist can freely leave his or her agricultural or grazing land for another when the productive potential is poor. In fact donation, in heritage and man labour, though with positive aspects lead to extensive exploitation and a short term use of resources. That why most of the peasants have to apply chemical fertilizer, composts, to improve the fertility of soils. While animal breeders must buy cotton cakes, ground nut cakes and dried grasses to feed their animals or go for transhumance in dry season.

Keywords: Appropriation, Management, Resource, Degradation, Vina-Adamawa 


\section{Introduction}

Natural resources that support human existence and welfare, when they are degraded, poor people suffer most (Murphree, 2005; ECOFAC, 2008). The ecosystem degradation is one the factors that contributes to the climate change effects (Watson, 1998) and he continued saying that the temperature changes will be accompanied by changes in the amount and patterns of precipitation leading to more floods and droughts in many areas in developing countries.

Cameroon, like some other sub-Saharan African countries has been plagued by a number of conflicting claims regarding land reforms, rights to land and over the management of natural resources (Oyono 2004; Oyono et al., 2005; Pascal 2008). The conflicts at times, lead to inter-ethnic disasters, farmer-grazier disputes, damages and loss of property and lives. The aggravation is the poverty situation which widespread in rural areas.

Like other divisions in Cameroon, the Vina Division in Adamawa region, the sustainable utilization of major natural resources including farmlands, pasturelands and water resources is worsened (Rippstein,1985, Yonkeu,1998, Boutrais, 2001) by the ecological and socio-economic crisis that worries the rural population. Indeed, mounting pressure upon natural resources with agro-pastoral and food productivity and illegal deforestation has contributed in the Vina division to significant need on the lands and ecological resources (Rippstein 1985).

Conflicts over land tenure for crop cultivation, housing and livestock production (Boutrais 2002) are frequent in the division. A phenomenon closely linked with unsustainable utilization of the land and its resources Agricultural Divisional Office of Ngaoundere (ADON 2010 ) is the ongoing land degradation in the division. This is a key barrier to maintaining and increasing the productive capacity of the agro-pastoral sectors. The immediate impact are the food insecurity and the poor economic growth for the division. The misuse of farmlands, grazing areas, livestock and water resources and poor management methods contribute to exacerbate land-related conflicts (Blackman 2008). Thus, caring and enhancing the ecosystem and natural resources management necessitate comprehensive and participative efforts.

\subsection{Contexts of Land Tenure in Cameroon and Statement of the Problem}

Land legislation enacted after independence did not only retain various European ideas and concepts of property (Teyssier 2003), but also diluted them with certain notions, which have been at disagreement with the indigenous land tenure principles. Seignobos (2002) argued that the laws and their execution are not fitting because power consideration and law designs are never involving the indigenous system. The legal responsibility for the management of natural resources falls on the Government through the issuing of licenses and certificates/titles and collection of revenue from them. At a practical level however, traditional communities, land tenure systems have persisted due to poor infrastructure, weak central government authorities. Dispersed rural settlements make awareness and enforcement of state law difficult (Egbe, 1995) to be implemented. Local groups of people have managed the land on which they live and the natural resources with which they are surrounded for 
millennia (Nelson et al., 2005). Indigenous African communities often developed detailed resource management systems (Fabricius, 2004), as have local communities throughout the world (Ostrom, 1990; Borrini-Feyerabend et al., 2004).

Policy and legislative reforms (often within the forest sector) in many developing countries are beginning to open up opportunities for state-backed, decentralized management (Joiris 1996). Today, local groups of pastoralists, farmers, and hunter-gatherers throughout Africa maintain many traditional systems of collective natural resource management, which help to sustain the livelihoods and cultures of millions of people

The legislative reform has been practically adopted (e.g. community forestry in Cameroon and Central African Republic). Despite recent reforms, centralized land tenure legislation is still a significant constraint in the regions of Cameroon (Russell et al., 2001).

Adamawa, is one of the 10th administrative region of Cameroon Republic. It is localized between the 6th and 8th degrees of the northern latitude and between the 10th and 16th degrees of the East longitude. It is named officially "Chateau d'eau du Cameroun" because many rivers take their sources from the region areas including Benoue, Deo, Banyo, Mbere and Vina rivers that flow to Logone. While Mbam, Kim, Djerem and Lom go to the Sanaga and Logone seas. All of them lead to three different lakes such as Niger and Chad ponds and Atlantic Ocean. The hydrography of the region is very rich. Many types of soils are found in the region, the climat is varied, the vegetation is diversified (I.E.M.V.T, 1974). The minimal monthly mean temperature varied from $16^{\circ} \mathrm{C}$ to $21^{\circ} \mathrm{C}$ (Aubreville, 1948).

Before 1980's, land in the village communities around the Vina belonged to the whole community. Traditional leaders acted as owners of the land and could lease it and hold it in trust for the future use of their populations.

By 1990's, demographic pressure due to migration in search for farmlands, pasturelands for investments in livestock, in crops for food and for markets, accidentally had controlled inter-ethnic relations and develops much interests in lands. Land legislation laws in the department and in all administrative offices did not only keep hold ideas and concepts of land property, but rather had weakened them. These concepts do not have agreements with the indigenous land tenure principles.

Vina division, from Adamawa region has been undergone a number of conflicting claims regarding rights over the occupation and management of farmlands, pasturelands and water resources between farmers and animals breeders, first land holders and the new arrivers. In rural areas, the search for new lands is multifaceted.The poverty situation of local people is aggravated by the reduced fertility of farmlands, dreadful conditions of pasturelands and the rapidly drying sources of water as soon as the raining season is ending ( early November).

The poorest rural people who are most dependent on biodiversity and other resources for their livelihoods suffer severely when those resources are impoverished.

Fertile lands are increasingly scarce in rural areas. New lands or bushes (considered as pasturelands for years) today, are converted into farms for crop cultivation or for urbanization. 
The socio economic crises are worse. The price of food items such as the kilogram of meat has doubled from 1400 to $2400 \mathrm{~F}$, the $100 \mathrm{kgs}$ bags of maize from 10000 to 20000 , that of groundnut from 25000 to $40000 \mathrm{~F}$ and that of millet from 10000 to $18000 \mathrm{~F}$ (DDAN, 2010, DRC, 2012).

Repeated conflicts between pastoralists and farmers, administrative authorities and traditional rulers are rampant throughout the Vina Division where livestock and crop producers co-exist. Everyone is in search to increase the production by overexploitation.

While the conservation and sustainable use of biodiversity is fundamental to achieve sustainable development and livelihoods since natural habitats, their component species and genes provide both goods for consumption and ecological services to maintain healthy environments. Therefore, social, economic and political implications are necessary to solve the issues. These solutions require prompt attention from the local society, academic and political communities. The objective of this paper is to know the actual causes of accelerated farmlands, pasturelands degradation and that of rapidly freshening water resources in the department. The result is a lower total welfare, particularly for the poor rural population.

\subsection{Background and Setting of the Ethnic Groups in the Vina Division}

The Vina Division site of study (appendix 1) deserved pastoral activities because of its potential grazing pasturelands and water availabilities (Boutrais, 1980). It was the first Division in Cameroon where animals breeding succeeded during the colonial periods (Boutrais, 1991) and 77\% health check centre is of the Adamawa regions were found in the Vina Division (IRZ et al., 1989). The availability and quality of the natural resources (grasses, water and fertile lands attracted many ethnic groups to install thereby. The government authorities encouraged local people to create familial and private organizations to benefit from the sponsor. About 26 Zoo-Centre were established in the Vina Division (MINEPIA, 2002) for the health supervision by the Cameroon government.

The four villages including Dibi, Mbang-Mboum, Mbé and Tourningal are the localities that constitute Vina Division. The two major activities including agriculture and pastoralism are dominating in those villages. At Dibi and Tourningal animal breeders represent 90 p.cent, while in the other two villages (Mbang-Mboum and Tourningal) farmers are predominant with (95 p.cent).

The word Mboum from Mbang-Mboum are the first occupiers, pioneers of Vina division especially for Ngoundere town. They came from Egypt by 1830's. They were originally metal and tools (hoes, cutlasses, knives etc) makers and they became farmers over time. Today they are the first maize, beans, and millet producers of the Vina division. They arrived when the lands were empty and very fertile for agriculture and for grazing. They were who gave lands to Foulbe and other ethnic groups in Ngaoundere (the actual headquarter) of the Adamawa region and that of Vina Division.

While in Mbé, Dii or Dourou ethnic groups were the first occupiers. Their origin is from the North region particularly from Toubouro village. They are actually the first yam and cassava producers of the Vina Division. They occupy the plain after the "falaise "called (Plaine Dii) 
The Foulbé and Mbororo whose origins were from Troua and Yola in Nigeria are animal breeders and arrived to the Vina Division before the years of independence. They used to come with their animals and went back as nomads. As time is going, they found the areas encouraging for pastoralism. Grasses, water resources were available throughout the years and the animals can be well feed here. Finally, they approached the traditional leader (Lamido) of Ngaoundere town. They negotiated to obtain grazing lands and for territory to stay with their animals. To thank the Lamido, (animals and money) are given to him. The Lamido authorized them to graze their animals on vast areas and for houses. As time is going, they allied to the local people (Mboum) by taking maring. They are said second occupiers of Vina division.

In Ngaoundere sub-division, the total cultivated lands for corn, millet, suit potato and beans have increased from 1500 to 12300 hectares from 1999 to 2012 respectively (DAAN, 2011).

Many other ethnic groups such as Haussa, Ibo, Yamouri from Nigéria, Gbaya from Central Republic of Africa, Mbororo, Damagara from Niger Republic and Laka from Chad have been familiarized with the first occupiers (Bronsvoort et al., 2002).

\subsection{Land Tenure Claims and Pressure on Lands}

Since 1983 with the creation of the state university of Ngaoundere the pressure on land, the increase of tenure claims over land and resource management are frequent with the ever-growing population in the Vina division Inefficiencies on land tenure, management and use of natural resources are observed in rural localities of the Vina division. These arise because property rights are not complete, not exclusive, not enforced, and not transferable. In addition, defined property rights and opportunities to exploit weaknesses in the task of such rights are often unclear.

Inefficiencies in the utilization of natural resources often arise because property rights are not complete, not exclusive, not enforced, and not transferable. In addition, defined property rights and opportunities to exploit weaknesses in the assignment of such rights are often unclear in Vina Division.

Before the colonial era, land in the village communities belonged to the whole community and traditional leaders acted as custodians of the land and could lease it and hold it in trust for the future use of their populations.

The law in Cameroon classifies land into three categories: State property, private property and national lands (Pascal 2008). State lands cover areas where traditional land tenure arrangements are respected. The government has control over all lands and can distribute them to private by issuing title rights or can takes them away if necessary for public uses. Therefore, traditional authorities do not have more power on these lands. As a results, inter-village conflicts and farmer-grazier disputes are very common, (Quan 1997; Pourtier 2000; Tchotsoua 2005); Ngwa et al. 2007).

Lack or weakness of land tenure security exacerbates natural resources management as the general population had little or no incentive to invest in land management for long term. Soil, 
vegetation and water conservation practices are only focusing on meeting their short-term economic needs such as the Mbororo transhumants.

In addition, powerful élites often manipulate incentives to their advantage. The result is lower total welfare, particularly for the poor. Inded, this research aims to identify what are the major modalities of land appropriation and analyze whether those modalities of tenure and the management practices contribute to the current farmlands, grazing areas degradation and water shortage observed in the Vina Division.

\section{Material and Methodology}

The study site (Appendix 1), the Vina division lies on about $18487 \mathrm{~km}^{2}$ and has been given recently two new sub-divisions (Gang-Ha et Yam Baka) in 2009, they include in total of five with the three first subdivisions, Bélel, Mbe et Ngaoundere. In 1999, the Vina population was 239445 inhabitants and has been estimated to reach 554802 by year 2010 by Tsapi (2002) and Tchotsoua (2005). Today the population of the division is estimated to be 610000 inhabitants.

Vina division is the first and excellent zone designated for pasture and agriculture since the years before independence in 1960s. Three major tribal groups were dominating including the Mboum, Dii and Foulbe. The Foulbe were the first animal breeders who arrived to the Division after the two other groups. The Mboum and Dii were already and were farmers. The region has a tropical climate with temperatures ranging from 22 to 25 degrees Celsus during raining seasons (April to October) and reaching 30 to 35 degrees Celsus during dry season (December to March) (Aubreville 1967; Rippstein 1985). The average rainfall is 1000 to $1500 \mathrm{~mm}$. In most areas, the high savannah trees and herbs are either, burned (appendix 3), cut severely degraded by overexploitation for grazing. The natural reserve lands or pasturelands are often encroached by settlements or banned for use as open grazing in Dibi and Tourningal. The agriculture is mainly rain fed and labor intensive in Mbang-Mboum and Mbe localities (Boutrais, 1994). The average of farm holding by individual is $1 / 4$ hectare. The ownership of a grazing land is by demarcating with sticks, herbs and iron wires and the average for each is one hectare. With the introduction of the 1974 legal land tenure, the traditional rulers and communities reflects their history of settlement and customary rules and concepts. The local customary rules consider that the lands should be given freely to those who are in need and who can stay in the village. In detail, they (traditional leaders) say, 'it helps to clear new spaces for habitat, for agriculture, ease increasing the population number and security in rural areas". The right to bushes is a collective one or a common law. The statement of respondents is that; "land belongs to everybody and no one has an absolute right to land and its resources".

\subsection{Research Methods}

This work is a part of Ph.D research program that took place from 2006 to 2010; I carried the program simultaneously at the Ngaoundere University and at the Institute of Agric Research for Development of Wakwa Ngaoundere. It included part of regional projects ARDESAC and PAFRA. 


\section{Macrothink}

Common qualitative methods used in data collection included on site observation, questionnaires, interview (semi-structured, structured or open interview and on group and individual discussions. For investigation, four villages including Dibi, Mbé, Mbang-Mboum and Tourningal were chosen for appraisal.

The above villages are selected because of the predominance of farmers and pastoralists in those localities. The four villages above represent the Vina Division activities in terms of agriculture and pastoralism.

Group discussion approaches to data collection were used mostly by participatory rural assessment, rural rapid appraisal. On the field, with two GPS, we walked all around farms, grazing areas for data records to determine the total spaces areas belonging to each village. Participatory approaches are used by CIFOR and CIAT.

For this work, it includes collecting information on institutions, groups of individuals, producers, NGOs affecting, rights to lands and management of natural resources.

The constraints or difficulties related to land tenure and management practices are collected. Frequencies of tenure modalities were compiled against constraint's frequencies in contingency tables for analysis.

The chi-square test, $\mathrm{HO}$ and $\mathrm{H} 1$ hypotheses at 0.05 probabilities are used to know if the tenure systems and management practices are responsible for the rapidly deterioration of farmlands, pasturelands and water shortage in the Vina Division.

This paper attempts to identify the major modalities of possessing farmlands, pasturelands and water, analyzes the management practices of those resources in one hand and at the other hand determines the impact of the modalities and management practices on the degradation of the above resources.

\section{Results and Discussion}

In common with other regions of Africa, in Cameroon and particularly in Vina division (Adamawa region) we have a diverse range of ethnic groups bringing a diversity of tenure systems. The figure1 below shows the period of the ethnic groups of setting in Dibi, Mbang-Mboum, Mbé and Tourningal localities of the Vina Division. 
1. Dibi

2. Mbang-Mboum

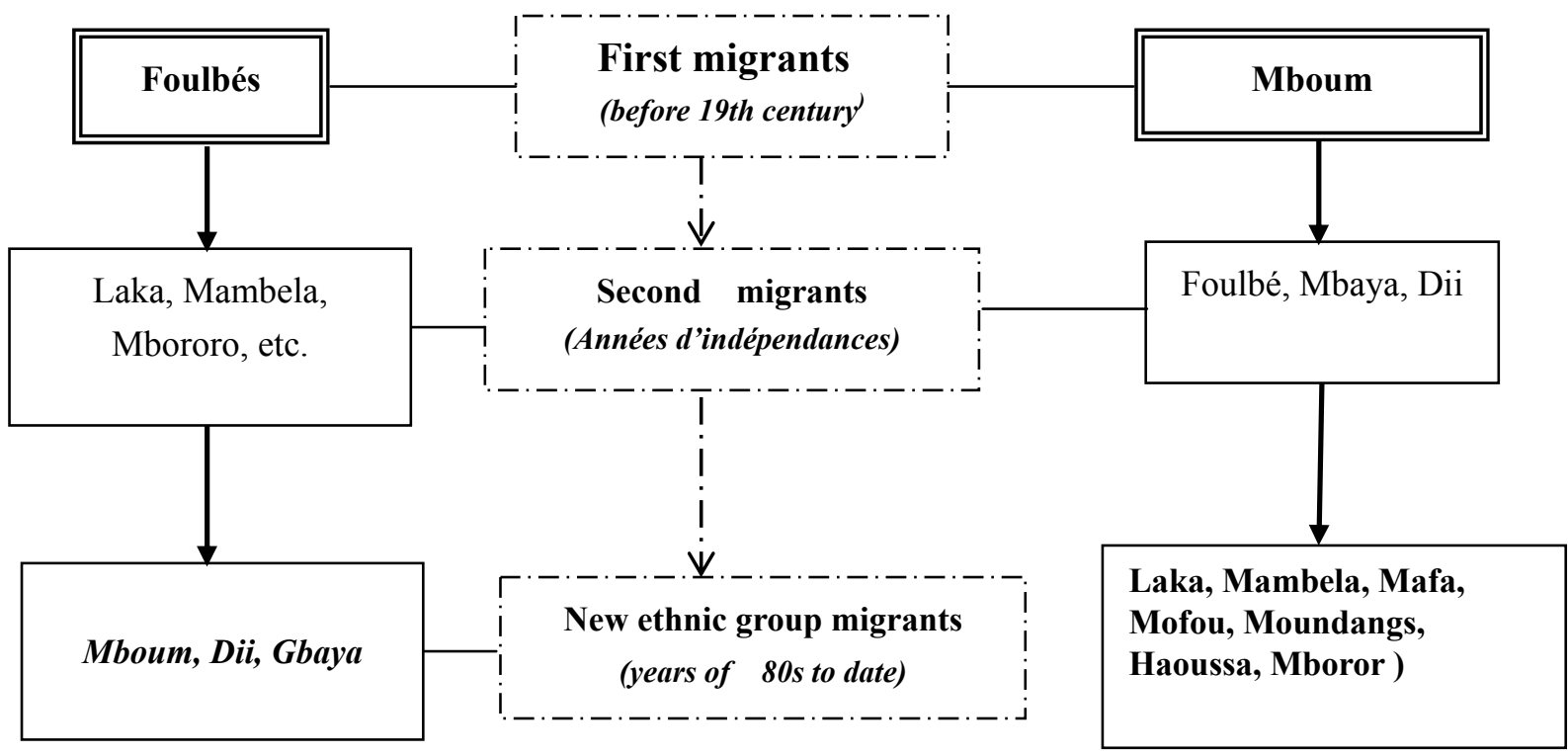

\section{Mbé}

4. Tourningal

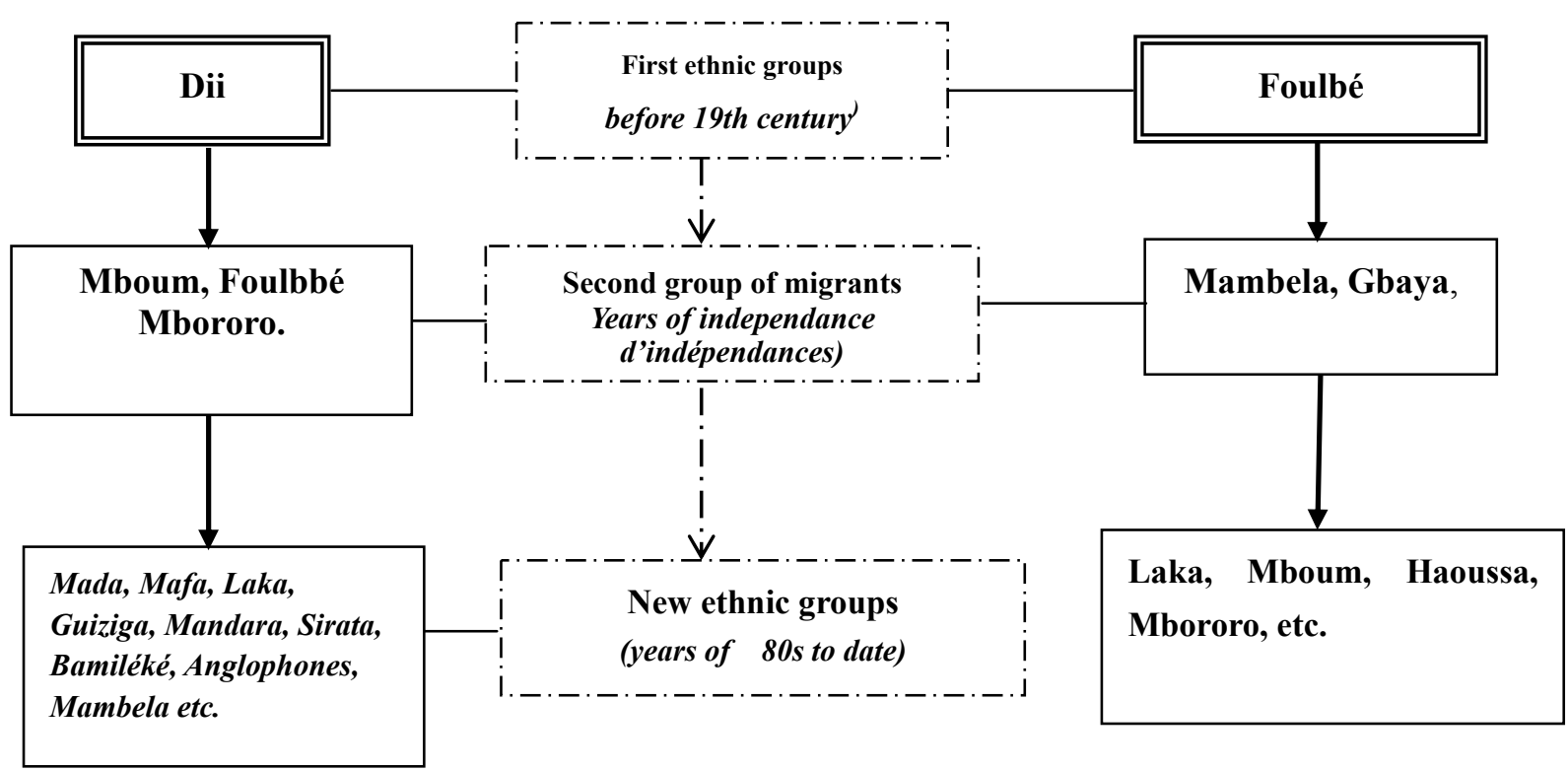

Figure 1. Periods of the setting of the ethnic groups in each village

Source: Field work 2008 /2009

The figure 1 shows that in Dibi and in Tourningal, the first occupiers were Foulbé tribes while in Mbang-Mboum locality, the Mboum were the first dwellers. They arrived there since the years of 1900s. The Dii were the first inhabitants or occupiers in Mbé. The recent migrants are Laka, Mambela, Mofou, Moudang, Bamilike, Bamenda, Haoussa, Gbaya etc. They started arriving to the villages by years of independence and up to date. Some of them 
are appointed for administrative works and others are in search of farmlands for grazing areas and for businesses.

After the periods of setting of the different ethnic groups in the villages from figure 1, below we analyze the ways of respondents to possess or access to farmlands, to pasturelands and their major constraints encountered during management.

Water are analyzed on two groups basis, that means pastoral and household water.

\subsection{Unsustainable Farmland, Grazing Land Management Practices and Bio-Fuel Activities in Vina Division}

The Vina Division witnesses high demographic pressure on land. At most time, the rising population provokes competition over natural resources; causes land degradation and accelerate the out-migration of poor people from place to place without possessing and access to land.

With a not well-defined property rights, an inappropriate land use like overgrazing and slash-and-burn farming practices (appendix 2), problems related to land at the localities are harsh. The farmers as the animal breeders move from one to another farm or grazing area as soon as its former productive potential is decreasing (Piot 1977; Audru 1980; Rippstein 1985 and Yonkeu 1993). Many vast farmlands and pasturelands are left aside or abandoned because of the decreasing fertility grade (appendix 3).

Encroachment on reserves and areas traditionally designed as pastoral lands exacerbates the conflicts among farmers, pastoralists and forest conservators in the Vina Division. Though (Oyono 2003) argued that the phenomena are prevalent in all northern regions of Cameroon because of the development of national parks, new camping of population and hunting areas.

The Adamawa Region has an estimated livestock of 6 million animals with $80 \%$ located in the Vina division (IRZ et al., 1989). They increasingly restricted the grazing spaces in the Vina division. They give rise to conflicts for access and managing pasturelands and water for livestock. Overgrazing and soil degradation (Oyono 2003; Regional Delegation of Ministry of Livestock, Fisheries and Animal Production 2006) are widespread in the Vina Division.

The degradation of herbs and trees, the destruction of micro-fauna and the misuse of water resources are key challenge issues all over the localities nearby the Vina Division. Many conflicts occur between land users, especially between crop farmers and pastoralists. If the issues are not accurately solved in those villages where population pressure and competing crop cultivation and livestock grazing activities accelerate depletion of the natural resource, the conflicts will be more severe.

Ongoing land degradation is a key barrier to maintaining and increasing the productive capacity of the agro-pastoral sector. Food insecurity is chronic on local markets. Given that increasing land productivity presents a key element to boost rural sector growth, local landholders increasingly view land degradation as an issue of vital importance. They are the causes and a consequence of persistent poverty in rural areas of the developing countries (World Bank 2008). The north and Adamawa Regions, which are characterized by fragile 
ecosystems, the increasingly land degradation is visible and begins to affect the regional overall crop productivity and water livestock (Ayonghe 2001).

Illegal and excessive cut of trees and burning of bushes (appendix 2) in Vina division are the consequences of over-harvesting of trees for fuel-wood, conversion of woodland for crop farms and for livestock food (herbs) production. The phenomena are worsened by the uncontrolled and inefficient systems of forest security officers called (agents des Eaux et Forêts). Deforestation is almost linked to overgrazing and hostile farming practices.

Beside the high demographic pressure on lands, many have taken sale of fuel-wood as permanent activities particularly Gbaya, Laka ethnic group communities commonly called "Mboum babal" They cut any tree and even in protected areas. During raining seasons, they use to fall fresh trees and wait ending November to cut it in pieces for sale. Other groups such as (Foulbe, Dii, Gbaya) who practice the activity only in dry seasons (from november to april). Boutrais (1994), Boutrais (2000), Quan (2000), Tchotsoua et al., (2002) and Tchotsoua (2005) who worked in the region particularly in Vina division on deforestation have reported that, people with low incomes, varied needs, aspirations and beliefs are among the factors that harm environmental resources of the Vina division. In the same way Ngouffo and Tchoffo (2001) who worked in the division reported that degradation started with the over clearing land for farming or for hunting of wildlife then the soil fertility loss occurred from the unsuitable agricultural and grazing management practices.

The soil infertility coupled with poor farming systems lead to poor crop outcome and environmental degradation (Kangalawe 2010). This is linked to weak capacity for sustainable land use and water controls. The inappropriate crop intensification under monoculture systems, disorganized expansion of agricultural production are the adopted practice of peasants of the developing countries (Blackman 2008).

\subsection{Major Groups of Soils of the Vina Division}

According to the findings of (Atlas Cameroon, (1954); Bachelier et al., (1957); Martin et al., 1966; Humbel, (1971) and Rippstein (1985) who analysed and classified the types of soils of the Adamawa Region and that of the Vina Division, completed with the fieldwork and observation, we found that there are two major groups of soils with the following characteristics:

\subsubsection{Ferruginous Soils}

These soils are found in Mbang-Mboum and Mbé localities. Generally, they are formed in tropical zones with two seasons including raining and dry seasons. They are localized on mountains or hills. The soils contain oxide and iron hydroxides. Their PH varies from 5.5 to 6.5. They are very poor in organic ingredients and are very rich in caly. They are not favorable for crop growing. That why farmers have to apply a lot agric inputs such as chemical fertilizers, composts and animal decays (fumure ou bouse de vache) to improve the fertility level of the soils. 


\subsubsection{Ferralitic Soils}

They make up the soils of Dibi and Tourningal villages. These soils are found in the savannah areas, they are ticker than ferruginous soils. They are localized on highlands where the water drain is excellent. They contain (kaolinite) red color elements and muddy clays. They are slippery in raining season and dusty in dry periods. Their PH varies from 4.5 to 5.6 and are said to be acid soils. They contain sands, quartz and volcanic trashes. They are richer in organic matters compared to ferruginous soils. They have sodium, nitrate but poor in humus. The soils are favorable for pasturelands during raining season but they become compacted in dry periods.

\subsection{Frequencies of Possession of Farmlands, Pasturelands, Use of Water and Problems} Encountered Per Village

The tables 1 and 2 below browse the frequencies of occupancy systems of farms, grazing areas and the use of water. All the constraints encountered during management practices of farmers and pastoralists were collected.

Table 1. Frequencies of tenure on farmlands and management constraints

\begin{tabular}{|c|c|c|}
\hline $\begin{array}{l}\text { Villages and } \\
\text { interviewed } \\
\text { respondents }\end{array}$ & $\begin{array}{l}\text { b. } \text { Ressources } \\
\text { / constraints }\end{array}$ & $\begin{array}{l}\text { c. water resources } \\
\text { / constraints }\end{array}$ \\
\hline Dibi -(100) & $\begin{array}{l}\text {-gift }=50 \% \\
\text {-man labour }=20 \% \\
\text {-inheritage }=30 \% \\
\text { constraints } \\
\text {-infertile soils }=70 \% \\
\text { - agric Inputs are expensive }=30 \%\end{array}$ & $\begin{array}{l}\text {-free }=80 \% \\
\text {-buying }=20 \% \\
\text { constraints } \\
\text { - need potable water }=65 \% \\
\text { - well s dry rapidly }=35 \%\end{array}$ \\
\hline $\begin{array}{l}\text { Mbang-Mboum } \\
(300)\end{array}$ & $\begin{array}{l}\text {-gift }=40 \% \\
\text {-man labour }=40 \% \\
\text {-inheritage }=47 \% \\
\text { constraints } \\
\text {-soils are infertile }=57 \% \\
\text {-agric Inputs are expensive }=43 \%\end{array}$ & $\begin{array}{l}\text {-free }=70 \% \\
\text {-buying }=30 \% \\
\text { constraints } \\
\text { - need potable water }=73 \% \\
\text { Wells dry rapidly }=27 \%\end{array}$ \\
\hline $\begin{array}{l}\text { Mbé } \\
(200)\end{array}$ & $\begin{array}{l}\text {-gift }=40 \% \\
\text {-man labour }=20 \% \\
\text {-inheritage }=47 \% \\
\text { constraints } \\
\text { Soils are infertile }=60 \% \\
\text {-agric inputs are expensive }=40 \%\end{array}$ & $\begin{array}{l}\text {-free }=40 \% \\
\text {-buying }=60 \% \\
\text { constraints } \\
\text {-need potable water }=45 \% \\
\text {-wells dry rapidly }=55 \%\end{array}$ \\
\hline $\begin{array}{l}\text { Tourningal } \\
(100)\end{array}$ & $\begin{array}{l}\text {-gift }=50 \% \\
\text {-man labour }=30 \% \\
\text {-inheritage }=20 \% \\
\text { constraints } \\
\text {-soils are infertile }=60 \% \\
\text {-agric inputs are expensive }=40 \%\end{array}$ & $\begin{array}{l}\text {-free }=80 \% \\
\text {-buying }=20 \% \\
\text { constraints } \\
\text {-need potable water }=35 \% \\
\text { - wells dry rapidly }=35 \%\end{array}$ \\
\hline
\end{tabular}


The table 1 above shows the frequencies of the ability to possess farmlands and water. It varied from village to another. The general perception is that respondents have customary rights (gift, inheritage and man labor) to possess or to access to farmlands.

But they buy (boreholes water) and water from local wells or rivers are free and animals drink directly from rivers or lakes.

Except in Mbang-Mboum where respondents possess farmlands by inheritage (47\%), in the three villages ( Dibi,Mbe and Tourningal), gift is the major way of possessing farmlands with $50 \%$ in Dibi, and Tourningal and 40\% in Mbang-Mboum and Mbé respectively. Respondents reported that under customary rules they collect natural resources such as fodder, fuel wood, fruits, leaves, pole woods and other products as much as for the household needs freely. They continue that these resources should be kept for the future generation and never could be sold The two major constraints encountered on farmlands are the infertility of soils and agric inputs are very expensive.

Well water are obtained freely in three villages with $80 \%, 70 \%$ and $80 \%$ at Dibi, Mbang-Mboum and Tourningal respectively. While in Mbe respondents buy much water $(60 \%)$. Beside the insufficiency of potable water in all villages, in Mbe traditional wells and rivers dry rapidly (55\%) as the raining season ends (early November).

Table 2. Frequencies on possession of pasturelands, getting pastoral waters and constraints

\begin{tabular}{|c|c|c|}
\hline $\begin{array}{l}\text { 1. Localities } \\
\text { and respondents }\end{array}$ & $\begin{array}{l}\text { Ownership frequencies of grazing } \\
\text { lands and constraints }\end{array}$ & Frequencies of getting water and constraints \\
\hline Dibi (150) & $\begin{array}{l}\text {-gift }=30 \text { ou } 20 \% \\
\text {-man labour }=40 \text { ou } 27 \% \\
\text {-inheritage }=80 \text { ou } 53 \% \\
\text { Constraints } \\
\text { - foods and veterinary input are } \\
\text { expensive }=27 \% \\
\text { Pasture lands are very poor }=73 \%\end{array}$ & $\begin{array}{l}\text {-free }=67 \% \\
\text {-buying }=33 \% \\
\text { Constraints } \\
\text { - need potable water }=43 \% \\
\text { Wells dry rapidly }=57 \%\end{array}$ \\
\hline $\begin{array}{l}\text { Mbang-Moum } \\
(20)\end{array}$ & $\begin{array}{l}\text { gift }=50 \% \\
\text { man labour }=50 \% \\
\text { Constraints } \\
\text {-food and veterinary inputs are } \\
\text { expensive }=40 \% \\
\text { Pasturelands are degraded }=60 \%\end{array}$ & $\begin{array}{l}\text { free }=75 \% \\
\text { buying }=25 \% \\
\text { Constraints } \\
\text { - need potable water }=70 \% \\
\text { - wells dry rapidly }=30 \%\end{array}$ \\
\hline Mbé (70) & $\begin{array}{l}\text { gift }=86 \% \\
\text { man labour }=14 \% \\
\text { Constraints } \\
\text {-food and veterinary inputs are } \\
\text { expensive }=50 \% \\
\text { Pasture lands are degraded }=50 \%\end{array}$ & $\begin{array}{l}\text { free }=71 \% \\
\text { buying }=29 \% \\
\text { Constraints } \\
\text {-need potable water }=21 \% \\
\text { - wells dry rapidly }=79 \%\end{array}$ \\
\hline $\begin{array}{l}\text { Tourningal } \\
\text { (150) }\end{array}$ & $\begin{array}{l}\text { gift }=29 \% \\
\text { man labour }=35 \% \\
\text { inheritage }=36 \% \\
\text { Constraints } \\
\text {-food and veterinary inputs are } \\
\text { expensive }=33 \% \\
\text { - pasture lands are degraded }=67 \%\end{array}$ & $\begin{array}{l}\text { free }=80 \% \\
\text { buying }=20 \% \\
\text { Constraints } \\
\text { - need potable water }=70 \% \\
\text {-wells dry rapidly }=45 \%\end{array}$ \\
\hline
\end{tabular}

Source: Field work 2008/2009 
The table 2 above shows the frequencies for possessing pasturelands of the localities. We can see that in two villages Mbang-Mboum and Mbé no one inherited grazing spaces. It indicates that the animal breeders are migrants and the first parents could not transfer grazing land to they children. They are given to those who worked (man labour) or "ont défriché". While in Dibi and Tourningal, the major mean of transferring grazind areas are inheritage $80 \%$ and $36 \%$ respectively.

Pastoral water are free $(67 \%, 75 \%, 71 \%, 80 \%)$ in all villages (Dibi, Mbang-Mboum, Mbe, Tourningal) respectively because animals get directly into rivers or lakes. Drinking (potable) water are bought but those who do not have money to buy are obliged to drink traditional well water or from rivers with all the risk of diseases.

The major constraints of pastoralists collected are grouped into four categories;

I-grazing lands are degraded; ii-food and veterinary inputs are very expensive. iii-the rapidly drying of rivers or wells and boreholes, iv -insufficiency of the potable water.

The World Bank (2010) reported that scarcity of water is increasing in all developing countries and this problem is expected to intensify in the coming years due to population growth.

The main structure of tenure systems seems to have a similar basis in majority of the communities of subsaharian countries (Quan, 2000; Mathieu, 1999). Roe et al., (2009) have reported a patrilineal system of land tenure inheritance, governed by a group of 'elites' or village chiefs or head family members to be familiar in all french colonial African countries. In the four villages (Dibi, Mbang-Mboum, Mbe and Tourningal, all lands are owned by clans of first occupiers.. Within each clan, some families have tenure rights over delimited areas. Sales are a relatively new idea, often are forbidden, particularly in Mbang-Mboum. Land may be lent or given to migrants to the villages for a specific period (growing season or a lifetime), but land status will stay for the first families or clans. Such transfers are not written officially on documents.

Village rules can prohibit certain areas or species (Joiris 1996) from being harvested, and enforcement can be through village elites, traditional authorities/or magic. Kumpel, (2006); Pourtier, (1989) reported the existence of traditional taboos or totems meaning that some species must be ignored or protected if encountered. Such species are great apes and chimps, they are not hunted due to their resemblance to man. They are avoided, particularly among muslim societies in the majority of sub-Saharan countries of Africa.

\subsection{General Perception of Respondents on State Lands, Decrees and On Property Rights} Awareness

To have an idea on the perception of respondents on state lands, decrees, and obtaining property rights on lands, we have interviewed all respondents and the table 2 gives the resume of their answers. 
Table 2. General perception of respondents on state lands and awareness on title rights (in \%).

\begin{tabular}{|l|l|l|l|l|}
\hline Tenure statements & Dibi & Mbang-Mboum & Mbé & Tourningal \\
\hline $\begin{array}{l}\text { I know the state domanial } \\
\text { lands }\end{array}$ & $4 \%$ & $0 \%$ & $5 \%$ & $8 \%$ \\
\hline $\begin{array}{l}\text { I never take notice on the } \\
1974,19976 \text { decrees }\end{array}$ & $100 \%$ & $100 \%$ & $100 \%$ & $100 \%$ \\
\hline $\begin{array}{l}\text { I have a certificate title on my } \\
\text { lands }\end{array}$ & $10 \%$ & $0 \%$ & $4 \%$ & $5 \%$ \\
\hline I never tried to do it & $90 \%$ & $100 \%$ & $96 \%$ & $90 \%$ \\
\hline $\begin{array}{l}\text { I want to do the certificate of } \\
\text { occupancy on all lands }\end{array}$ & $50 \%$ & $0 \%$ & $40 \%$ & $60 \%$ \\
\hline $\begin{array}{l}\text { I do not need a title right on } \\
\text { lands }\end{array}$ & $50 \%$ & $80 \%$ & $60 \%$ & $40 \%$ \\
\hline $\begin{array}{l}\text { There are many Problems } \\
\text { before obtaining the title }\end{array}$ & $20 \%$ & No answers & $10 \%$ & $10 \%$ \\
\hline $\begin{array}{l}\text { I am not happy with the } \\
\text { administrative officers charged } \\
\text { on issuing title because of } \\
\text { bribes, time wasting, loosing } \\
\text { of files) }\end{array}$ & $80 \%$ & No answers & $90 \%$ & $90 \%$ \\
\hline
\end{tabular}

Source: Field work 2008/2009

Reading the table above, we find out that majority of respondents do not have information about state lands and decrees. Only 4\%, 5\% and 8\% know something about state lands and decrees in Dibi, Mbe and in Tourningal respectively. Few tried to get titles $(10 \%, 4 \%$ and $5 \%$ ) respectively. These few are pastoralists who want to secure grazing lands. In Dibi, Mbe and Tourningal localities, the common reasons for failure $((80 \%, 90 \%$ and $90 \%)$ to proceed to get tenure right are inability to bribes, to follow the long procedure of files, time wasting and loosing or the misuses of files by the regional or sub-divisional officers of tenure affairs. The lack of communication, education on land tenure issues and the lack of influential political person in the family or in the locality are is also an handicap for the peasants to get promptly the titles. If present the powerful élites often manipulate incentives to their personal advantages In Mbang-Mboum none of respondents knows state domains lands, none about decrees.Sale of land is not permitted and none can attempt to have a certificate of occupancy (titre foncier. ${ }^{1}$ ) because it is strictly forbidden by the traditional laws and rules.

Respondents do not have notice the 1974 and 1976 Decrees, which give details and guide citizens on how to proceed and to obtain certificate right. Officially, no one can be proprietor of the actual lands that they actually holding. With this weakness or inefficiency of the application of state decrees lands are poorly managed and unsustainable agric and grazing practices are rampant in the Vina Division particularly in the localities where the research

\footnotetext{
${ }^{1}$ Here we were not able to see the physical document of the certificate of occupancy. We agreed with the respondents sayings. Establishing a title right on land is a strange issue and difficult for the respondents in the appraisal areas. At Dibi and Tourningal localities, the traditional leaders authorize to do so, but the long time taking and corruption discourage the respondents to go ahead. While in Mbang-Mboum and Mbé it is strictly forbidden to think about title lands. The Djaouro ou traditional leaders of these two villages do not allow for it.
} 
took place from 2006 to 2010 . The agric lands are obtained by gift, inheritance or by manual labor passing through Djaouro or traditional leader who can issue an authorization paper to the user against some money, crops or animal depending on the capacity of the person. Grazing areas are commonly used. Animals have free access to the space if the vegetation productivity is favorable. No one respects the potential capacity of productivity of the pasturelands (bushes) that constitute the set aside space of the village. Rivers, trees and mountains constitute the major materials of permanent status of each village. In addition, powerful élites often manipulate incentives to their personal advantages. That is why new comer investors do not have guaranty to put much money on lands since they cannot benefit from bank credits or from state or NGO or enterprise in case of state public services (administrative office, school, hospitals, roads) building. As no peasant had a title right on land in Dibi, the villagers were payed on informal basis by the BREZILIAN enterprise (ENTRADE) that constructed the N0 1 national road, which passes through Dibi locality

\subsection{Total land spaces belonging to each village}

During the fieldwork, we worked throughout the bushes in each village and with the records taken from GPS (geographical position system), we are able to know the total areas.

Table 4. Land spaces occupied per activity obtained from GPS records (in hectares)

\begin{tabular}{|l|l|l|l|l|}
\hline Areas & Localities & Mbang-Mboum & Mbé & Tourningal \\
\hline & Dibi & Ma & 275,1 ha & 37,5 ha \\
\hline urbanism & 16,0 ha & 46,73 ha & 2776,8 ha & 149,9 ha \\
\hline Agric lands & 132,27 ha & 3954,96 ha & 3800,0 ha & 3999,0 ha \\
\hline pasturelands & 1516,1 ha & 4562,8 ha & $\mathbf{6 8 5 1 , 9}$ ha & $\mathbf{4 1 8 6 , 4}$ ha \\
\hline Total & $\mathbf{1 6 4 5 , 3 7}$ ha & $\mathbf{8 5 6 4 , 4 9}$ ha &
\end{tabular}

Source: Field work, $2008 / 2009$

From the table we can read that, Dibi is the village with the smallest space value (1645,37 ha). While Mbang-Mboum has the highest $(8564,49$ ha) followed by Mbe with 6851,9 ha and Tourningal with 4186,4ha. Mbe comes first for urbanized areas with 275,1ha and Dibi the last with 16.0 ha.

\subsection{Independence Chi-2 Test Analysis}

Here we compile the frequencies of land appropriation against frequencies of constraints in contingency tables. If the value of $\mathrm{x}^{2}$ calculated (obtained from data collected) is lower than that of $\mathrm{x}^{2}$ table at 0.05 probability, we said that the hypothesis (HO) is accepted and this implies that the management practices of respondents are contributing to the degradation of farmlands, pasturelands and the insufficiency of water in the localities. While H1 is accepted when the value of $x^{2}$ calculated is higher than that of the table, therefore the management practices of respondents do not contribute to farmslands, grazing spaces degradation and water scarcity in the villages. The results of constraints of respondents against property rights frequencies are summarized in (table 5) below. 
Table 5. Analysis of the chi-2 test of independence

\begin{tabular}{|l|l|l|l|l|l|}
\hline ZONES & Dibi & Mbang-Mboum & Mbé & Tourningal & $\begin{array}{l}\text { chi-2 table } \\
\text { value at 5\% }\end{array}$ \\
\hline Agric farms & $\begin{array}{l}49.99 \\
\text { H1 accepted }\end{array}$ & $\begin{array}{l}0.311 \\
\text { HO accepted }\end{array}$ & $\begin{array}{l}0.21 \\
\text { HO accepted }\end{array}$ & $\begin{array}{l}1.2 \\
\text { HO accepted }\end{array}$ & 3.84 \\
\hline Pasturelands & $\begin{array}{l}4.04 \\
\text { H0 accepted }\end{array}$ & $\begin{array}{l}6.18 \\
\text { H1 accepted }\end{array}$ & $\begin{array}{l}\text { H1accepted } \\
\text { Hing }\end{array}$ & 16.0 H1accepted & 5.99 \\
\hline
\end{tabular}

Sources: Field work 2008/2009

The table 5 above gives us the result of the test of independence. In three villages ( Mbang-Mboum, Mbé, Tourningal), the hypothesis H0 is accepted for farmlands misuse,so the management practices of respondents contribute to the degradation of farmlands and water resources but in Dibi (H1) is true. This means that the management practices of farmers in Dibi locality do not contribute to the degradation of soils. In this case, the farmers of the three other villages can be trained on sustainable technique of management for conservation. But the independence test shows that the pastoralists of Dibi are responsible of the actual ruined grazing lands of the village. All pastoralists of the Dibi village are Foulbe and Mbororo whose practices are at the traditional level up to date. Since (1985), Rippstein has pointed out these observations. Nomads with huge number of herds stay and/or cross the village when the raining season ends. Here, they move from one to another grazing land as soon as the fodders are scarce or if animal disease is widespread in the area..

In Mbang-Mboum, Mbe and Tourningal the respondents do not contribute to the degradation of grazing lands. Nevertheless, they should be encouraged on confined management system of pastoral water resources in Mbe in particular where the villagers suffer much from water scarcity in general. In Mbang-Mboum and in Mbe the majority of respondents are farmers see table 1. The pastoralists are minor compared to farmers in these two villages. Only (20) from 320 interviewed in Mbang- Mboum and (70) from 270 in Mbé are nomads Foulbe and Mbororo pastoralists. They move all around neighboring countries (Chad, Nigeria and Central African Republic) from November to June.Watson (1998) argued that, when biodiversity is misused, its extensive decline has impacts on land and water resources degradation at the global level. Excessive deforestation, bush fire activities are widespread in the Vina Division. In the UN, (2009) quick guide to reduce emission from deforestation in developing countries, it has been pointed out that the major sources of Carbone release are the uncontrolled cut of trees and extensive bush fire practices. As revealed by Murombedzi, (2001), welfare and huge benefits can be obtained from improving and sustainable use of resources.

Water, one of the essential resources of life, needs to be protected and used with care. Currently, one-fifth of the Earth's population does not have access to safe drinking water, and about one-third lacks adequate sanitation. 


\subsection{Records on Water Resources, Population and Households}

To have an idea of the total population, the number of households by year 2011, I did an exceptional work to meet the traditional rulers and elites after my field works that end in $2008 / 2009$. So I was able to get an estimate of the total population number and that of households (ménages) of each village by ending December 2011 period.

To get the entire water resources of each village, we entered house to house and worked all around the areas (bushes and farms) of the localities. With the land survey and participative dialogue, we recorded all traditional wells, boreholes, rivers and lakes of the four villages (Dibi, Mbang-Mboum, Mbe Tourningal)..The table below summarizes the general records.

Table 6. Record on water resources, population and households in 2008/2009

\begin{tabular}{|l|l|l|l|l|}
\hline $\begin{array}{c}\text { 1.Water } \\
\text { resources }\end{array}$ & Dibi & Mbang-Mboum & Mbe & Tourningal \\
\hline Wells & $28(59 \%)$ & $37(86 \%)$ & $38(78 \%)$ & $54(90 \%)$ \\
\hline Boreholes & $17(35 \%)$ & $3(7 \%)$ & $10(20 \%)$ & $3(5 \%)$ \\
\hline Rivers & $2(4 \%)$ & $3(7 \%)$ & $1(2 \%)$ & $3(5 \%)$ \\
\hline Lake & $1(2 \%)$ & 0 & 0 & 0 \\
\hline 3.Households & 100 ménages & 350 ménages & 400 ménages & 250 ménages \\
\hline
\end{tabular}

Sources: Field work 2008/2011

The table 6 above gives us the number of population from 2008 to 2011, of households, of wells, boreholes, rivers and lakes. From the records, Mbe has the highest number of population (2300) and households (400) in 2009 followed by Mbang-Mboum with (2100) and (350) respectively. From the four villages Dibi has the lowest population (650) and households (100) numbers. This can be justified by the fact that the two localities attract more people because of the agric lands availability. Here the majority of inhabitants are farmers. From the land survey we found that 300 respondents out of 320 were pure farmers in Mbang-Mboum and 200 out of 270 in Mbe. The two villages have more space for agric activities (see table 4) The first occupiers of Mbang-Mboum and Mbe are excellent farmers and they produce about $60 \%$ of corn, beans, millets gnams of the Vina division.

In term of water resources Tourningal comes first with 54 wells and Dibi with boreholes (potable water). While Mbang-Mboum with the highest number in population has only 3 boreholes that supply potable water. The worst was that by 2009 ending one of the boreholes was not useful. Mbe has more problems on potable water because out of 10 boreholes existing,only 2 were functioning during our passage and the wells dry rapidly by November when the raining season is ending see (photo annexe 3) that shows people ( men, women, girls) around an open dread well in Mbe. Tourningal is the village where the water scarcity is minor. Out of 54 wells, only 10 were malfunctioning, that means 44 were operational and 3 boreholes, 3 rivers supply water throughout the year. 


\subsubsection{Insufficiency of Potable Water Supply in the Localities}

To have an idea about the insufficiency of potable water per household we divided the total number of boreholes of each village per the total number of households of each village.

Table 7. Ratio of boreholes and households

\begin{tabular}{|l|l|l|l|l|}
\hline \multirow{2}{*}{ Borehole / Household } & \multicolumn{3}{|l|}{ Boreholes and residence } \\
\cline { 2 - 5 } & Dibi & Mbang-Mboum & Mbe & Tourningal \\
& $3 /(100)$ & $3 /(350)$ & $2 /(400)$ & $3 /(250)$ \\
\hline Ratio values & 0.03 & 0.009 & 0.005 & 0.012 \\
\hline
\end{tabular}

Source: Field work $2008 / 2011$

The table 7 shows the ratio of boreholes by households or residence. The reading showse that in Mbe the population suffers most from potable water scarcity with 200 houses depending on 1 borehole. In Mbang-Mboum, 1 borehole supply potable water to about 123 houses. The scarcity of potable water in developing countries has been reported by (OMS, 2004) and (ONU, 2002) in their annual reports on improving and increasing conscious on water in developing countries. Watson and others (1998) argued that because of lack of water for sanitation and hygiene in developing countries, poorer populations are the most vulnerable to water-borne diseases. The World Health Organization (WHO) estimates that more than 5 million people die each year from diseases caused by unsafe drinking water.

\subsection{Evaluation of Population Growth of the Villages}

We were able to calculate the annual means growth of the population using TAMA (taux annuel moyen d'accroissement) formula defined as follow by Robert, PAEN (2005):

$\left.\mathrm{TAMA}=(\mathrm{V} 1 / \mathrm{V} 0)^{1 /(\mathrm{T} 1-\mathrm{T} 0)} 1\right) \times 100$ Э

$\mathrm{T} 0$ is the initial year and $\mathrm{T} 1$ is the second year. Here $\mathrm{T} 1-\mathrm{T} 0=1$

Where V1 is the value of second year population and V0 is the population of the initial year

Table 8. Annual means population growth of the villages

\begin{tabular}{|l|l|l|l|l|}
\hline $\begin{array}{l}\text { Years and annual } \\
\text { means growth }\end{array}$ & $\begin{array}{l}\text { Dibi's } \\
\text { (population number) }\end{array}$ & $\begin{array}{l}\text { Mbang } \\
- \text { Mboum's } \\
\text { (population) }\end{array}$ & $\begin{array}{l}\text { Mbe's } \\
\text { (population number) }\end{array}$ & $\begin{array}{l}\text { Tourningal's } \\
\text { (population number) }\end{array}$ \\
\hline $\mathbf{2 0 0 8}$ & 500 & 1900 & 2000 & 700 \\
\hline $\mathbf{2 0 1 1}$ & 650 & 2100 & 2300 & 850 \\
\hline TAMA formular & $(1.3)^{0.3}-1 \times 100$ & $(1.1)^{0.3}-1 \times 100$ & $(1.1)^{0.3}-1 \times 100$ & $(1.2)^{0.3}-1 \times 100$ \\
\hline $\begin{array}{l}\text { Annual means } \\
\text { growth values }\end{array}$ & $10 \%$ & $3.5 \%$ & $5 \%$ & $7 \%$ \\
\hline
\end{tabular}

Source: Field work 2008/2011 
From the table we read that Dibi and Tourningal have the highest annual means population growth with $10 \%$ and $7 \%$ respectively. For Dibi this high population growth rate can be justified by the construction of the No1 tarred road (route bitumée) (Yaounde -Ngaoundere) started in 2009 passes across the village. Therefore, many people migrate to the village. Today all officers of the company have their offices and engines are there. In addition to that may be during the land survey periods, nomads or transhumant passed or were camping in those villages because of the availability of water and grazing lands that cannot available in Mbe and in Mbang-Mboum localities. Mbang-Mboum has the lowest annual means growth population because of the location of the village. The village is a little bit far from tarred road that goes to Toubouro. Grazing lands are scarce due to the growing areas for farm. In Mbang-Mboum and in Mbe farmers is the majority of population. However, Mbe is the extreme sub-division of Vina Division and is boundary with the North Region. Many people coming from the North and Fare North regions prefer to stay first there before reaching Ngaoundere town.

\section{Conclusion}

At the end of this research work we retain that gift, inheritage and manual labor) are the major modalities to possess and access to lands and resources in the Vina division. Those are local rights over land and resources. The transactions among the members are made without written official documents. The traditional leaders hold the lands. Sale of lands are strictly forbidden by the traditional leaders particularly in Mbang-Mboum and Mbé localities. Therefore, they do not give guarantee to conventional conservation and investors. Conflicts between local groups and powerful elite's actors, including politicians and private investors, land officers and traditional leaders remain widespread across the localities.

The chi-2 analysis test show that the modalities of land appropriation and management practices coupled with some natural parameters (soils structures and geographical localization of the Vina division) contribute to the speedily deteriorating farmlands, pasturelands and water shortage in the Vina Division. From the analyses, we observed that deforestation and bush fire practices are uncontrolled. Trees have multiple uses including for firewood, roofing and fencings the farms. Some ethnic groups (Mboumbabal, Laka,Gbaya) consider sale of firewood as a source of domestic income for their livelihood.

The increase water shortage particularly in Mbang-Mboum and Mbé localities is the great challenge of traditional authorities, villagers and political leaders. For the two localities, the potable water supply is fare from satisfaction. From the appraisal we see that 1 borehole supplies water to 123 households in Mbang-Mboum and to 200 residences in Mbé.

By early November, some wells and boreholes dry completely and the population is obliged to drink water from rivers with all risks of water born diseases.

Water resources in general are insufficient in all villages. Beside the water needs for agriculture, the high demand for potable water particularly in Mbang-Mboum and Mbé, are the actual challenges of the respondents. With the actual population growth observed, water-resources planning and management incentives should be implemented. With the 
sponsor of the government and other NGOs, recycling domestic wastewater is important. Building houses in the way of facilitating the collect and conserving raining water are the innovations to be taught to the villagers of the vina Division.

A co-management of resources between central authorities and local communities that share rights and responsibilities under control of locally elected villagers can improve sustainable management of resources in the Vina division. Though already operational in some countries of West Africa (Merlet (2011) local communities with full authority control everlastingly the local resources. Access and harvesting of those local resources within their management areas will ease and improve their annual incomes. This type of management in the Vina division can reduce the illegal activities such as deforestation, bush fire practices, overgrazing.

Constrained by weak processes of land officers, limited financial resources and corruption, the respondents are discouraged to proceed for title rights. Therefore, we call upon the policy makers and local population to promote a harmonized and sustainable working calendar of lands and natural resources.

Offering training on agrarian reform, as well as providing decentralized models of natural resource control to indigenous can encourage the local population of the Vina Division to adapt for climate change effects. The fight against desertification and the conservation of bio-diversity (already started in some council in Cameroon) should be intensified and well followed from top down to the local communities.

\section{Acknowledgement}

I would like to thank my Ph.D. supervisors Prof Tchotsoua M. and Prof Ango S. M. in geography Department from Ngaoundere University for their endeavor to finalize this work. I acknowledge the help of Dr AOUDOU from Ngaoundere University and of M. Ganota from National high school of Maroua who helped me on the field and in map design. I appreciate the help of Amougou and Henrietta from IRAD Ngaoundere who assisted me during the fieldwork appraisal. I recognize the assistance of the former General Manager (ZOCK Simon) of IRAD who allowed me to apply for this Ph.D. program. I acknowledge the assistance of the former Vina Divisional head officer (Haman Dairou) who gave me an authorization letter to the subdivision head officers, traditional leaders for the fieldwork. I am grateful to IRAD, BAD, ARDESAC, PAFRA projects and my hierarchies' officers for the financial support for this research project.

\section{References}

Atlas De La Republique Unie Du Cameroun. (1980). Paris, Jeune Afrique (les Atlas d'Afrique) 72p.+cartes.

Aubreville A. (1948). Les régions à longues saisons sèches du Cameroun et de l'Oubangui-Chari. Ecologie et Phytogéographique forestière. In: Richesse et misères des forêts de l'Afrique noire francaise. Paris, Soc.Ed.géogr.marit. colon.1948. pp.81-131. 
Audru J. Et Boudet G. (1980). Pâturages de la zone Sud de la République Centrafricaine et Adamaoua Cameroun. Maisons -Alfort, I.E.M.V.T. Paris.

Ayonghe S. (2001). A quantitative evaluation of global warming and precipitation in Cameroon from 1930-1995 and projections to 2060: Effects on the environment and water resources. In: CM Lambi, EB Eze (Eds.): Readings in Geography. Bamenda: Unique Printers, pp. 142-155.

Bachelier G. (1957). Etude pédologique de la plaine de la Vina (N'gaoundéré-Wakwa). Yaoundé O.R.S.T.O.M./I.R.C.A.M. +Annexes.

Blackman, A. (2008). Can Voluntary Environmental Regulation Work in Developing Countries? Lessons from Case Studies. Policy Studies Journal, 36(1), 119-141. [Online] Available: $\quad$ http://www.justice.gov.nt.ca/pdf/ACTS/Environmental_Protection.pdf. http://dx.doi.org/10.1111/j.1541-0072.2007.00256.x

Borrini-Feyerabend G, Pimbert M, Farvar M, Kothari A., \& Renard Y. (2004). Sharing Power: Learning by Doing in Co-management of Natural Resources Throughout the World, IIED/IUCN/CEESP/CSD/CMWG, Tehran / Gland.

Boutrais J., (2001). «Tchabbal», montagne pastorale peule (Cameroun, Nigeria, Centrafrique). In: BART F., MORIN S et SALOMON J-N. (Sous la direction de,) Les Montagnes tropicales: Identités, mutations, développement.Table ronde Bordeaux-Pessac, 27-28 novembre.DYMSET CRET, Pessac.

DAAN. (2012). Rapport annuel des activités agricoles de la Délégation Départementale de l'Agriculture de la Vina.

Diaw, C. Si Nda Bot Et Ayong. (1997). Culture itinérante, occupation des sols et droits fonciers au Sud-Cameroun, Réseau foresterie pour le développement rural,

Diaw C. Et Oyono P. R. (1998). Dynamiques et représentations des espaces forestiers au Sud Cameroun: Pour une relecture sociale des paysages, Bulletin Arbres, Forêts et Communautés Rurales $n^{\circ} 15$ et 16 .

Dilys R. Fred, N., \& Chris S. (2009). Community Management of Natural Resources in Africa; Impacts, experiences and future directions; published by the International Institute for Environment and Development (UK).

DRCN. (2012). Rapport annuel des activités de sensibilisation de la Délégation Régionale de Commerce de Ngaoundéré

ECOFAC. (2008). Les zones Cynégétiques villageoises (République centrafricaine). ([Online] Available: http://www.ecofac.org/Composantes/ZonesCynegetiques Villageoises.htm

Egbe S. (1995). Rights of Individuals in Natural Resource Utilisation in Cameroon. Paper Presented in Seminar on Utilisation of Natural Resources. Kribi: WWF, May 28 to 31, 1995. 
Fabricius C. (2004). The fundamentals of community-based natural resource management. In Rights, Resources \& Rural Development: Community-based Natural Resource Management in Southern Africa, Fabricius C, Koch E (eds.). Earthscan; 3-43.

Humbel F. X. (1971). Carte pédologique de Ngaoundéré 10 à 1/50 000. Centre de Yaoundé, Cameroun, ORSTOM. Note explicative: +carte.

Joiris D. (1996). Importance des terroirs coutumiers pour la conservation: réflexions à partir du programme ECOFAC au Cameroun, au Gabon, au Congo et en République Centrafricaine, Actes du colloque panafricain sur la gestion communautaire des ressources naturelles et le développement durable, 24-27 juin 1996, Harare, Zimbabwe

Kangalawe, R., \& J. Lyimo. (2010). Population dynamics, rural livelihoods and environmental degradation: some experiences from Tanzania. Environment, Development \& Sustainability, 12(6), 985-997. http://dx.doi.org/10.1007/s10668-010-9235-y

Martin D. Et Segalen P. P. (1966). Carte pédologique du Cameroun oriental au 1/1000 000. Centre de Yaoundé, Cameroun, ORSTOM. + Note explicative.

Martin I. (2002). Appui aux groupements de producteurs laitiers de la zone périurbaine de Ngaoundéré (Cameroun). Mémoire de DESS. CNEARC/Université de Montpellier I 2002/CIRAD-EMVT, Montpellier 60p. +annexes.

Mathieu P. (1999). Les paysans, la terre, l'Etat, et le Marché: Sécurisation et formalisation endogène des transactions foncières en Afrique; in Lavigne Delville: Réperage des pratiques populaires d'usage de l'écrit dans les transactions foncières en afrique rurale travail de GRET /IED, 250p.

Minef, Pnud Et Gtz. (1994). Diagnostic général de la situation de l'environnement dans la province de l'Adamaoua. Document de base. MINEF, Yaoundé.122p.

Minepia. (2002). La stratégie sectorielle de l'élevage, des pêches et des industries animales, rapport annuel MINEPIA, Yaoundé, Cameroun, 53p.

Minepia. (2010). La stratégie sectorielle de l'élevage, des pêches et des industries animales, MINEPIA, Yaoundé, Cameroun.

Ministere De L'environnement Et Des Forets. (2003). Manuel des procédures d'attribution et des normes de gestion des forêts communautaires au Cameroun, deuxième édition, draft-janvier 2003, Yaoundé, 65 p.

Merlet M. (2011). Les droits sur la terre et les ressources naturelles et Diversité des ayants droit et des droits sur la terre et sur les ressources naturelles en Afrique de l'Ouest: quelques exemples, Comité technique, foncier et développement, disponibles sur [Online] Available: http://www.agter.asso.fr/IMG/pdf/d

Murombedzi J. ( 2001). Committees, Rights, Costs \& Benefits. In African Wildilfe and Livelihoods: The Promise and Performance of Community Conservation, Hulme D, Murphree M (eds.). James Currey; 244-255. 
Murphree M. (2005). Congruent Objectives,Competing Interests, and Strategic Compromise: Concept and Process in the Evolution of Zimbabwe's CAMPFIRE, 1984-1996. In Communities and Conservation: Histories and Politics of Community-based Natural Resource Management, Brosius JP (ed.). AltaMira Press; 105-147.

NEPAD. (2004). Promouvoir une gestion durable des ressources naturelles et la protection de l'environnement; Rapport du colloque des pays africains; Alger. Plan d'action du NEPAD.

Ngouffo R., \& Tchoffo B. (2001). Culture and Sustainable Land Management of Natural Resources in Africa. Paper Presented in Conference on the Cultural Approach to Development in Africa. Dakar: African Centre for Applied Forestry and Development Research, December 10 to 14, 2001.

Ngwa C. N., Ngalim An, Kum V. (2007). Farmer-grazier crises and conflict resolution in Menchum division of the north west province of Cameroon: Reflections from the field. Journal of Applied Social Sciences, 6(1 and 2): 234-250. Ngwasiri CN 2001. European Legacy on Land Legislation in Cameroon. In: CM Lambi, EB Eze (Eds.): Readings in Geography. Bamenda: Unique Printers, pp. 341-348.

Nelson F, Ole Makko S. (2005). Communities, conservation, and conflicts in the Tanzanian Serengeti. Third Annual Community-based conservation network seminar: turning natural resources into assets, Savannah Georgia, forthcoming. [Online] Available: http://sandcounty.net/assets/chapters/assets_chapter_5.pdf). Accessed 27/10/2011

OMS. (2004). Amélioration de l'approvisionnement en eau et de l'assainissement dans le monde: coûts et avantages

ONU. (2002). Rapport de la Banque mondiale et gouvernements membres des Régions d'Afrique sur la gestion des ressources en eau. Findings; journal; publication périodique du Centre;In; la Gestion de l'Information, de la Technologie et la Connaissance (Knowledge, Networks, Information and Technology Center - KNIT). Washington D.C., 85 p.

Ostrom E. (1990). Governing the Commons: The Evolution of Institutions for Collective Action, Cambridge University Press. http://dx.doi.org/10.1017/CBO9780511807763

Oyono, P. R. (2004). Institutional deficit, Representation, and Decentraliszed Forest Mangement in Cameroon. Environmental Governance in Africa Working papers.J.C.Ribot. Washington, D.C.,World Resources Institute; 1-36.

Oyono, P. R., Kouma, C., \& Mala, W., (2005). Benefits of forest in Cameroon. Global structure, issues involving access and decision-making hiccoughs. Forest policy and economics, 7(3), 357-368. http://dx.doi.org/10.1016/S1389-9341(03)00072-8

Pamo Tedonkeng E., Et Yonkeu S. (1989). Etude de comportement de quelques espèces fourragères introduites dans le Ranch du Faro. Adamaoua. In: Séminaire Régional sur les fourrages et l'alimentation des ruminants. IRZ/IEMVT Ngaoundéré (Cameroun).16-20 novembre 1987. Etude et Synthèse de l'IEMVT N 30: 413-425. 
Pascal, A. A. (2008). Ministre des domaines et des affaires foncières. Les 100 questions de l'usager pour bien comprendre l'obtention du titre foncier. Une production du groupe citoyen pour la Recherche et la Documentation, 48p.

Piot J. (1969). Végétaux et pâturages des savanes de l'Adamaoua au Cameroun REV.ELEV.MED.VET. Rapport général sur les études de meilleur temps de repos à la fauche. Ngaoundéré, Cameroun. Station fourragère de Wakwa, 112p.

Pnud. (2002). Rapport «Notre avenir à tous» de la commission des Nations Unies sur l'Environnement, le développement économique et social. Conditions du développement durable Quebec.Canada, 25p.

Pourtier R. (2002). Savanes africaines: des espaces en mutation, des acteurs face à des nouveaux défis. Actes du colloque de Garoua; Cameroun, Ndjamena, Tchad, PRASAC.

Quan J. (2000). Land Tenure, Economic Growth and Poverty in sub-Saharan Africa. In Evolving Land rights, policy and tenure in Africa. C. Toulmin et Quan eds. London.

Rippstein G. (1985). Etude sur la végétation de l'Adamaoua. Evolution, Conservation, Régénération et Amélioration d'un écosystème pâturé au Cameroun. Etudes et synthèses de l'I.E.V.M.T. n 14 , Maisons-Alfort.

Robert M. O., Pean. (2005). Manuel pratique d'élaboration de la carte éducative provinciale et Projet d'Appui à l'Education Nationale (PAEN).Ambassade de France au Burkina Faso

Russell. D., \& Tchamou, N. (2001). Soil fertility and the generation gap: The Bênê of southern Cameroon. People managing forests: The links between Human Well-being and Sustainability. C. J. P. Colfer and Y.Byron. Washington, DC, RFFand CIFOR: 229-249

Seignobos C. (2002). Sortir de l'oralité comme moyen de sécurisation des droits fonciers. In Jamin J.Y., Seiny Boukar L. Savanes africaines: des espaces en mutation, des acteurs face à de nouveaux défis.Actes du colloque, mai 2002, Garoua.

Teyssier A. (2003). La régulation foncière au Cameroun, entre communauté et citoyenneté. Annales d la FALSH, no Spécial, (sous presse).

Tchotsoua M. (2005). Evolution Récente des Territoires de l'Adamaoua central: de la spatialisation à l'aide pour un développement maîtrisé. Vol 3. Mémoire original et projet de recherche.

United Nations Framework Convention On Climate Change. (2009). A Quick Guide to reduce Emissions from Deforestation in Developing countries; Approaches to Stimulate Action as an Agenda Item under the UNFCCC. [Online] Available: http://unfccc.int/methods_science/redd/items/4615.php (May 30, 2009)

Watson, R.T. (1998). Protecting Our Planet, Securing Our Future: Linkages Among Global Environmental Issues and Human Needs. Washington, D.C.: United Nations Environment Program, U.S. National Aeronautics and Space Administration, World Bank. 


\section{Macrothink}

World Bank. (2008). Forests Sourcebook: Practical Guidance for Sustaining Forests in Development Cooperation. Washington, DC, the World Bank.

Yonkeu S. (1993). Végétation des pâturages de l'Adamaoua (Cameroun): écologie et potentialités pastorales. Th. Doct. Ecologie appliquée. Université de Rennes.

\section{Glossary}

ADON: Agric Divisional Office of Ngaoundere

ARDESAC: Appui de Recherche et Développement des Savanes de l'Afrique Centrale

BAD; Banque Africaine de Développement

CIAT: Centre International d'Agriculture et de Technologie

CIFOR: Centre for International Forestry Research

DAAN: Délégation d'Agriculture d'Arrondissement de Ngaoundéré

DRC: Délégation Régionale de Commerce

ECOFAC: Conservation et Utilisation Rationnelle des Ecosystèmes Forestiers D'Afrique Centrale

GTZ: Deutsche Gesellschaft für Technische Zusammenarbeit

I.E.M.V.T: Institut de l'Elevage et du Médicament Vétérinaire des pays Tropicaux

IRAD: Institut de Recherche Agricole pour le Développement

IRZ: Institut de Recherche Zootechnique

MINEF: Ministère de l'Environnement et Forêt,

MINEPIA: Ministère de l'Elevage des Pêches et Industries Animales

NEPAD: New Partnership for African Development

OMS: Organisation Mondiale de la Santé

PAFRA: Projet d'Appui à la Foresterie Rurale et à l'Agroforesterie

PAEN: Projet d'Appui à l'Education Nationale

PNUD: Programma des Nations Unies pour le Développement

TAMA: Taux Annuel Moyen d'Accroissement

UNFCCC: United Nations Framework Convention on Climate Change

WHO: World Health Organization 


\section{Ml Macrothink}

\section{Appendix}

Appendix 1. Site of study

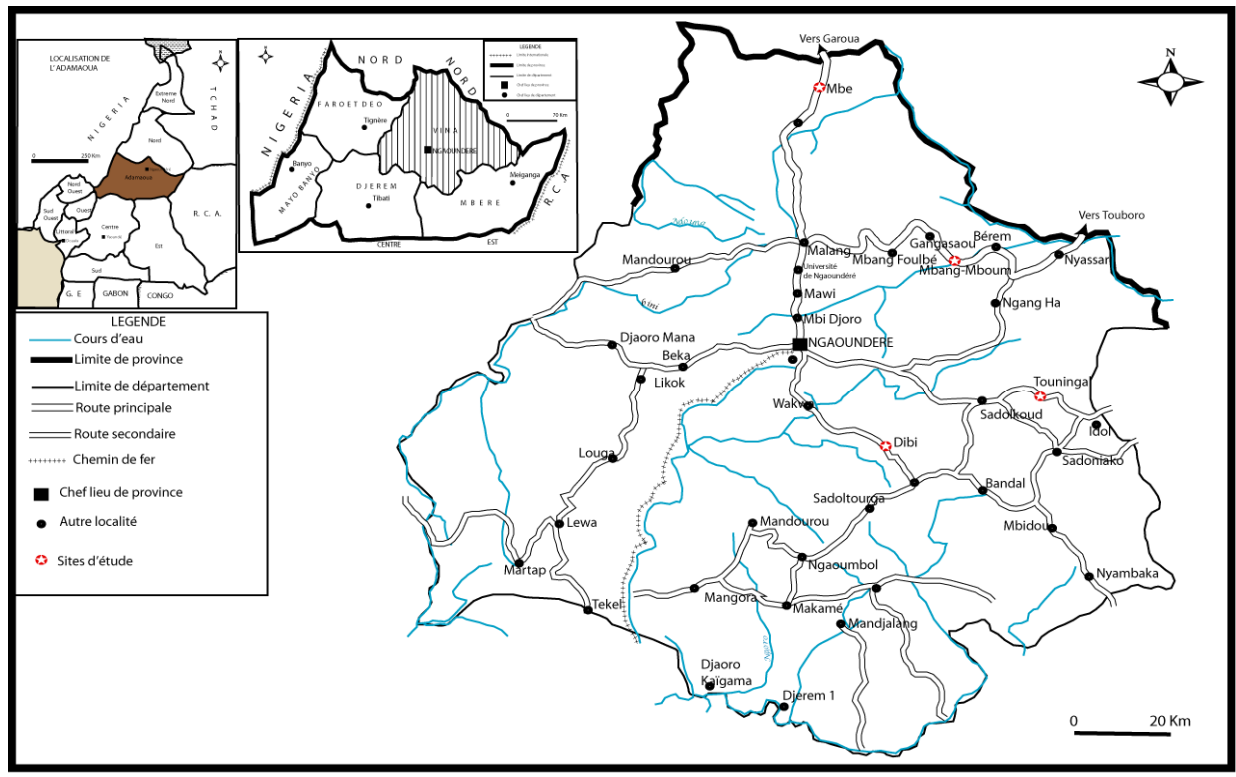

Figure 1. Site of study Vina division and localities

Source: Ganota and Tchotsoua, LG, Un, Ndéré 2007

Appendix 2. People around a dreadfully local well in Mbé (November) and an inappropriately managed local well in Mbang-Mboum locality

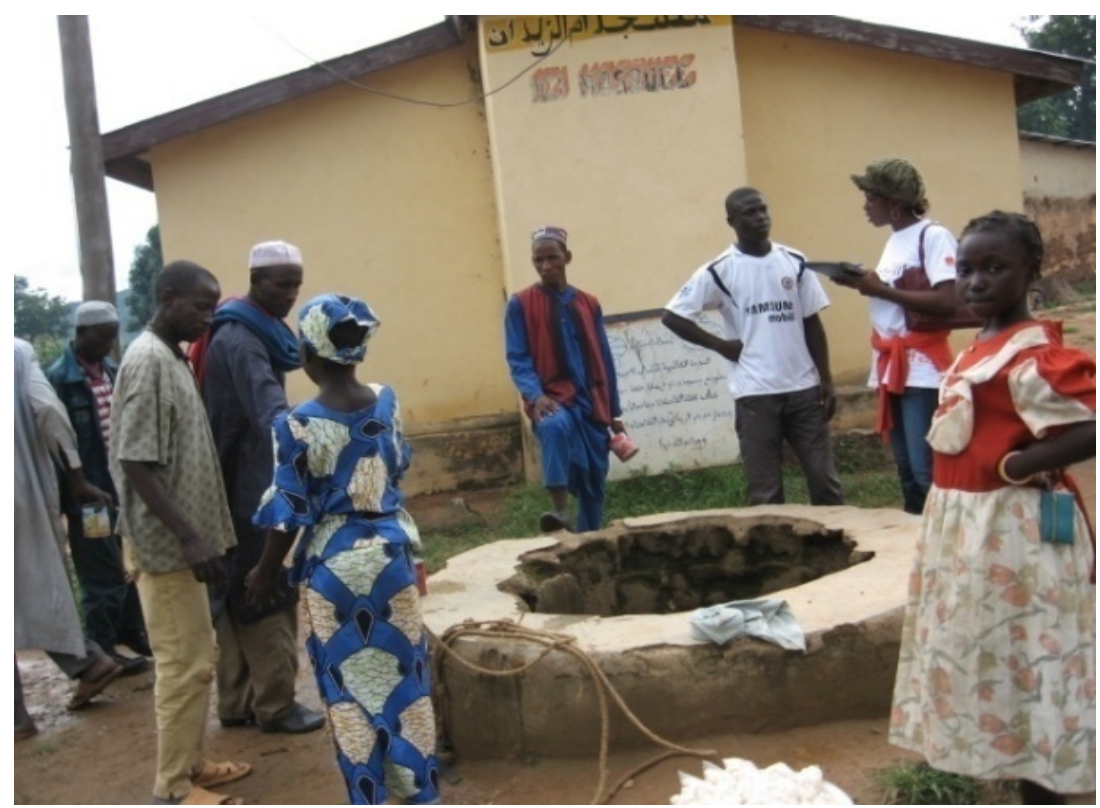

Photo 1. People around an open dreadful well by November (in Mbe locality)

Source: Ahmadou field work 2008/2009 


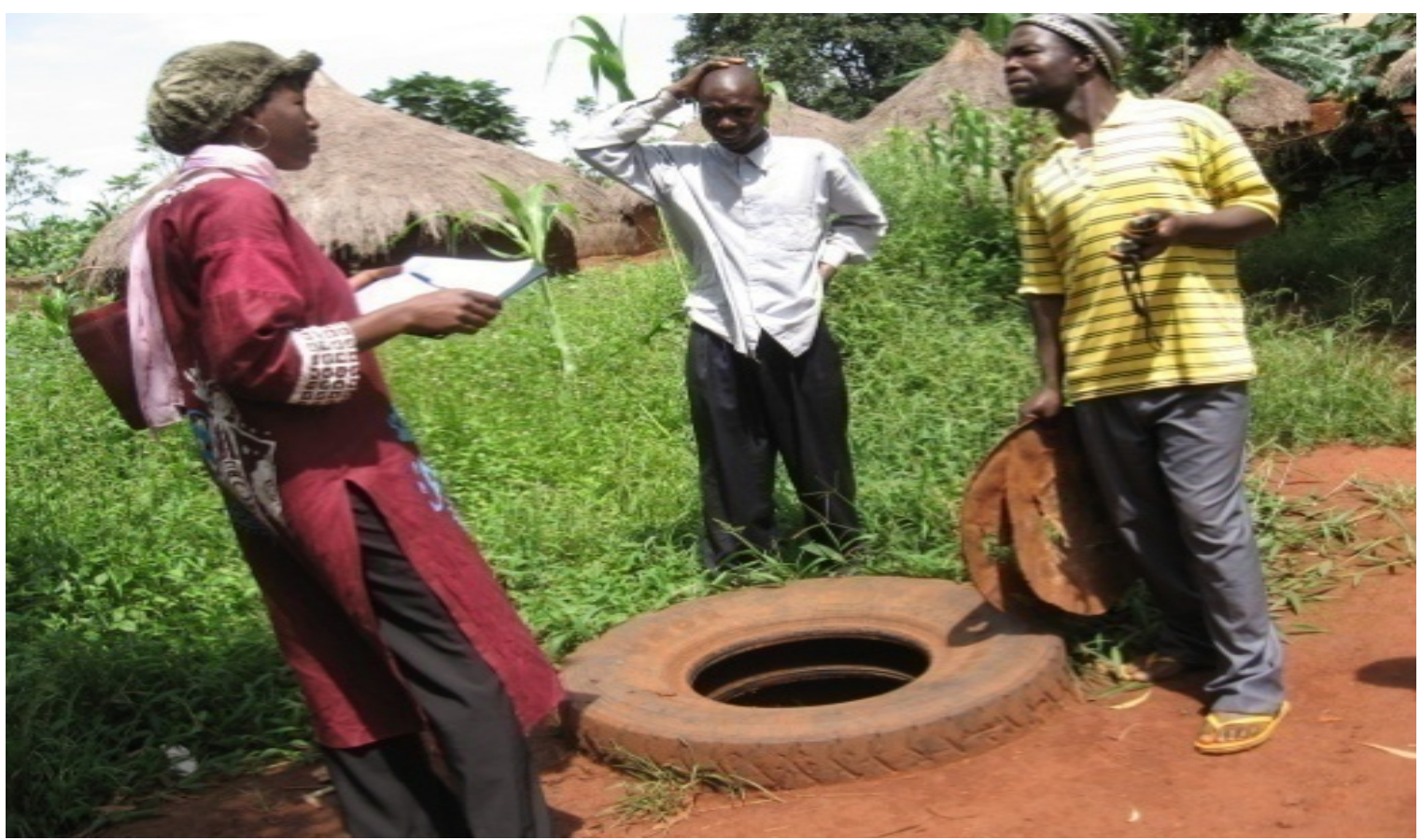

Photo2. Local well inappropriately managed in the house in August ( Mbang-Mboum locality)

Source: Ahmadou field work 2008/2009

Appendix 3. Animal grazing on a corn farmland after the harvest and a dried pastureland after bush fire practices in April in Dibi locality

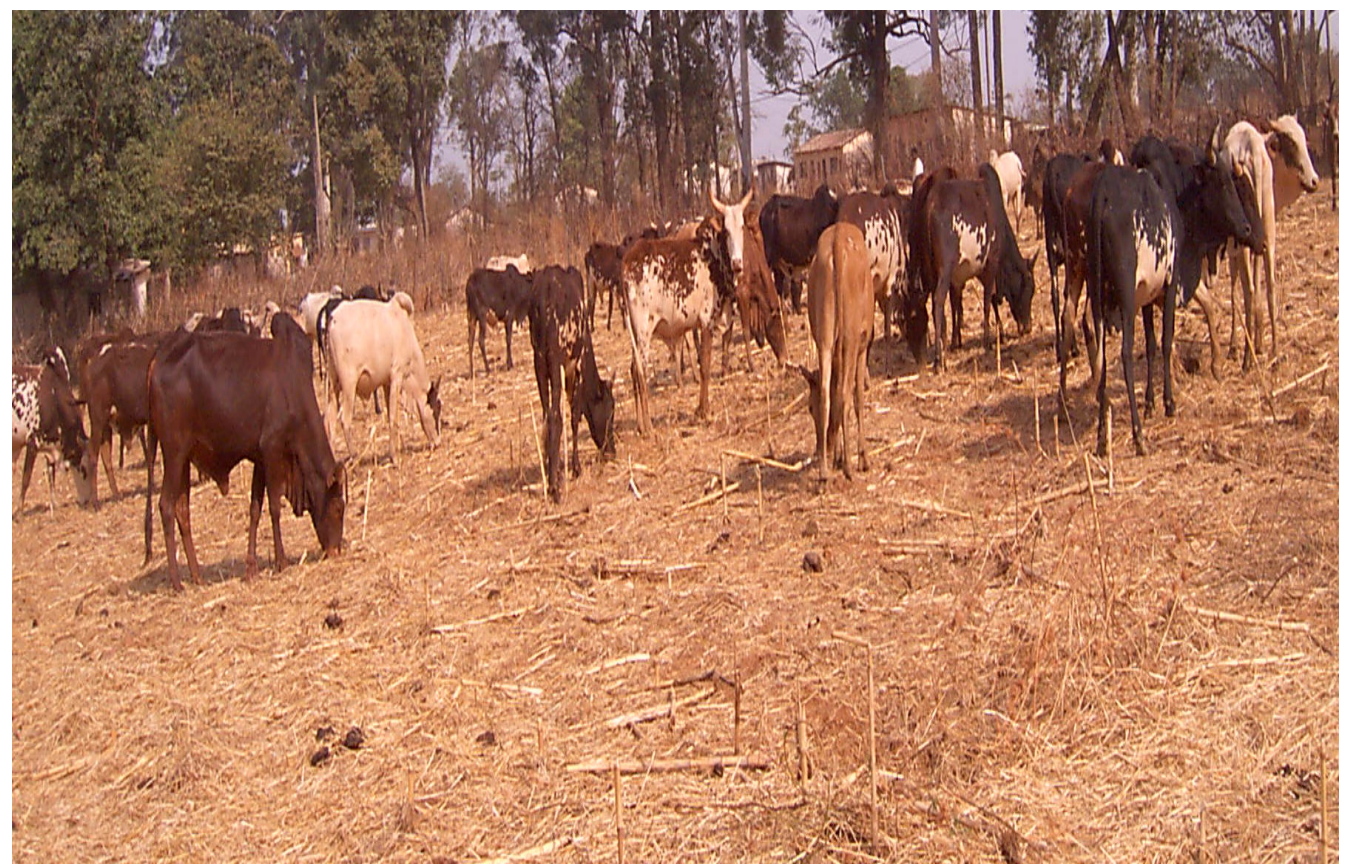

Photo 2. Animals grazing on corn farmlands after the harvest Vina Divion.

Source: Ahmadou field work 2008/2009 


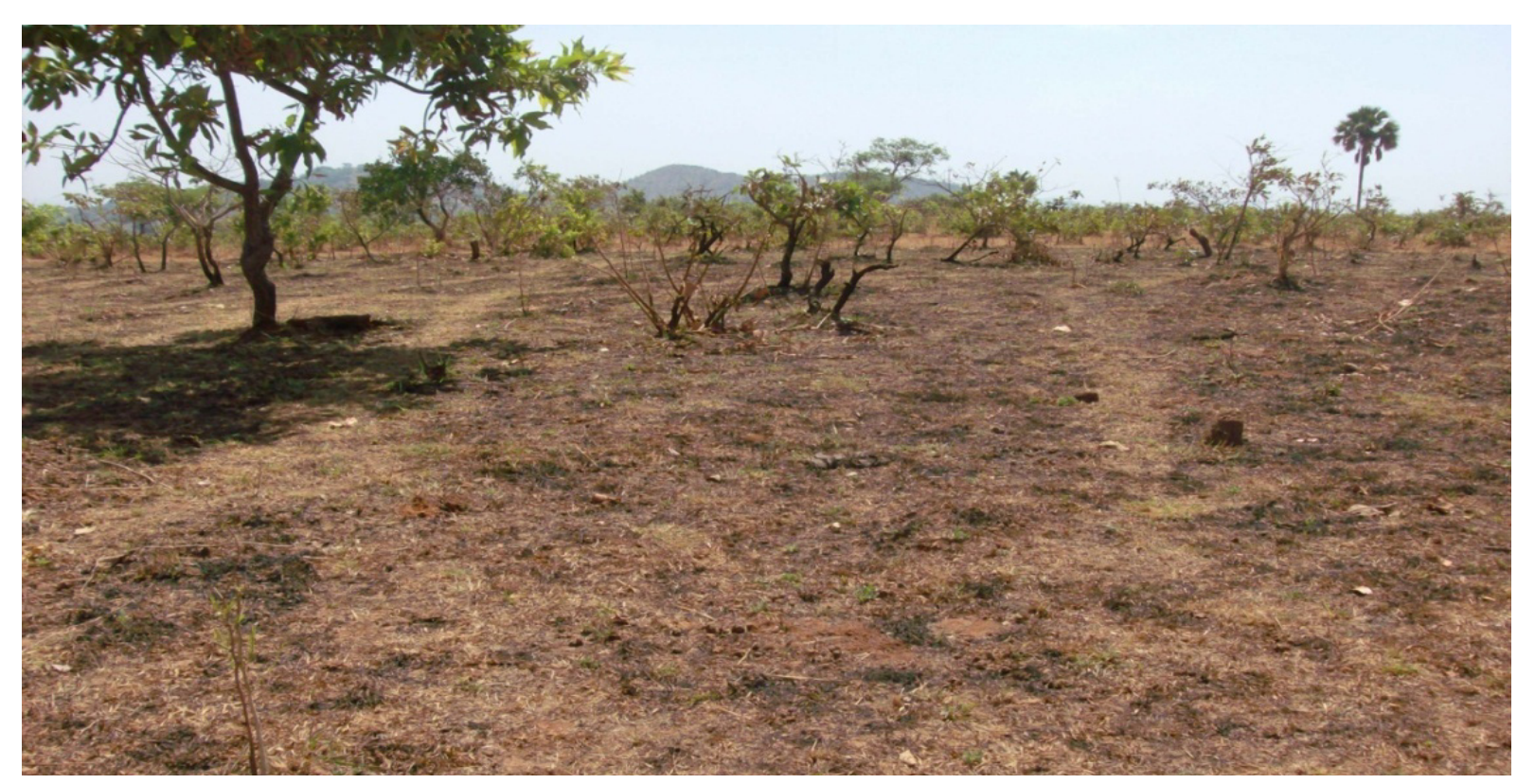

Photo 3. Pastureland after a bush fire in April (Dibi locality)

Source: Ahmadou field work 2008/2009

Appendix 4. Infertile, packed down grazing land by the passageway of animals in Tourningal locality

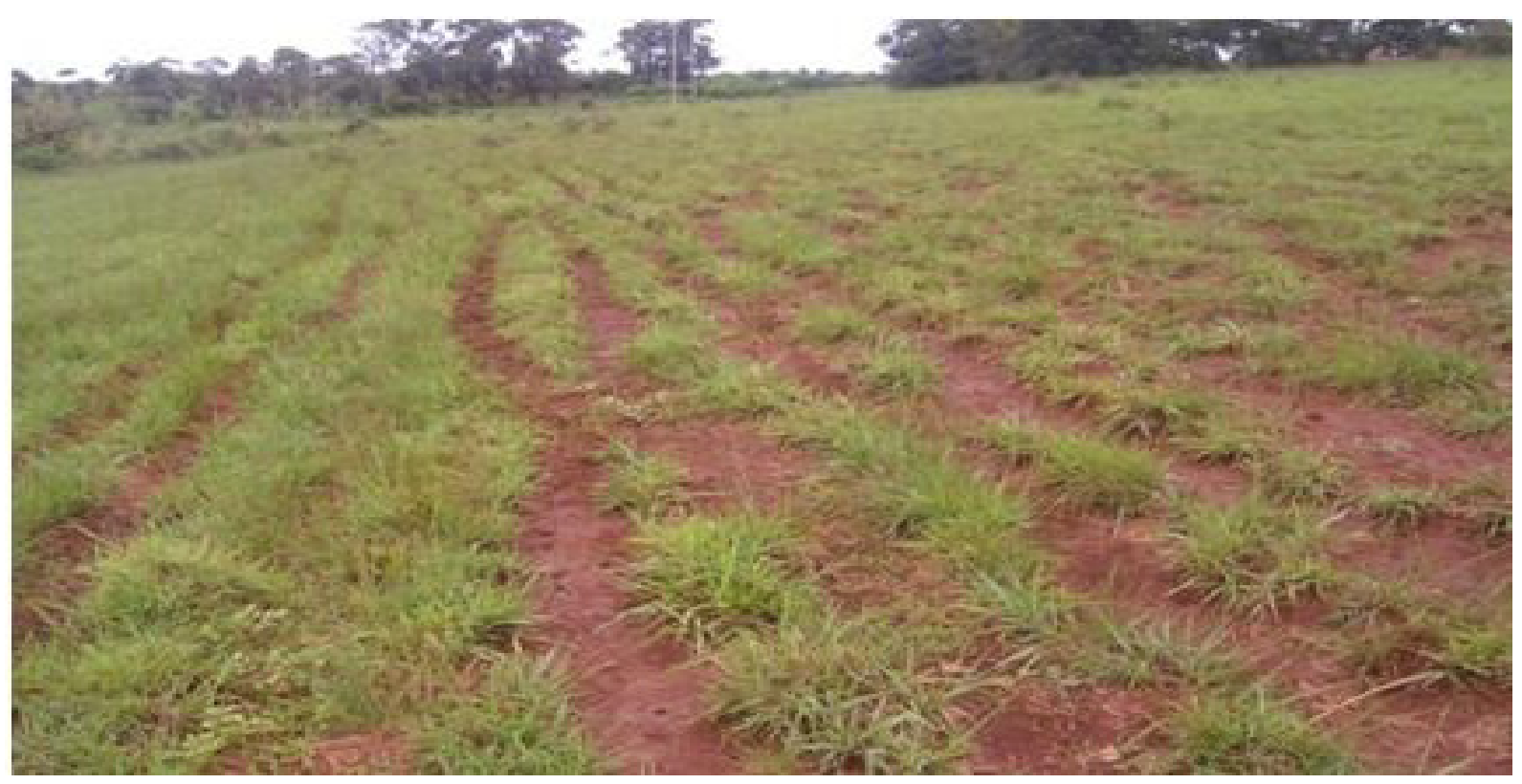

Photo 3. Grazing land is packed down by the passageway of animals and is infertile (in Tourningal locality)

Source: Ahmadou field work 2008/2009 